\title{
Radiation exposure, young age, and female gender are associated with high prevalence of RET/PTC1 and RET/PTC3 in papillary thyroid cancer: a meta-analysis
}

\author{
Xuan Su, ${ }^{1, *}$, Zhaoqu $\mathrm{Li}^{1, *}$, Caiyun $\mathrm{He}^{2, *}$, Weichao Chen ${ }^{1}$, Xiaoyan Fu ${ }^{1}$, Ankui Yang ${ }^{1}$ \\ ${ }^{1}$ Department of Head and Neck, Sun Yat-sen University Cancer Center, State Key Laboratory of Oncology in South China, \\ Collaborative Innovation Center for Cancer Medicine, Guangzhou, China \\ ${ }^{2}$ Department of Molecular Diagnostics, Sun Yat-Sen University Cancer Center, State Key Laboratory of Oncology in South \\ China, Collaborative Innovation Center for Cancer Medicine, Guangzhou, China \\ *These authors have contributed equally to this article and thus are regarded as the co-first author \\ Correspondence to: Ankui Yang, e-mail: yangak@sysucc.org.cn
}

Keywords: RET/PTC, papillary thyroid cancer, radiation, biomarker

Received: October 12, $2015 \quad$ Accepted: February 02, 2016

Published: February 23, 2016

\section{ABSTRACT}

Background: RET/PTC rearrangements have been identified as a specific genetic event in papillary thyroid cancer (PTC). We conducted this meta-analysis to identify an enriched population who were more likely to occur RET/PTC fusion genes.

Methods: All relevant studies in the PubMed, Web of Science, and Embase databases were searched up to June 2015. The studies found were screened according to our inclusion and exclusion criteria. All analyses were performed using STATA software.

Results: Eventually, 38 eligible studies comprising 2395 participants were included. Overall analysis indicated that radiation exposure contributed to increased $R E T / P T C$ risk $(O R=2.82 ; 95 \% C I: 1.38-5.78, P=0.005)$. Stratified analysis according to RET/PTC subtype and geographical area showed that this association was restricted to the RET/PTC3 subtype (OR = 8.30, 95\%CI: 4.32-15.96, $\mathrm{P}<0.001)$ in the Western population. In addition, age $<18$ years, i.e., young age, was associated with higher prevalence of $R E T / P T C 3(O R=2.03,95 \% C I: 1.14-3.62, P=0.017)$, especially in the radiation-exposure subpopulation ( $O R=2.35,95 \% C I$ : $1.01-5.49, P=0.048)$. The association between female gender and RET/PTC1 risk was more significant in the PTC patients without radiation exposure $(O R=1.69,95 \% C I: 1.04-2.74, P=0.034)$.

Conclusion: Both radiation exposure and young age are associated with increased risk of RET/PTC3 and that female gender is associated with higher prevalence of $R E T / P T C 1$ in the subpopulation without radiation exposure. The RET/PTC status in combination with radiation exposure, age, and sex should be considered in the differential diagnosis of suspicious PTC.

\section{INTRODUCTION}

Rearrangement involving the RET proto-oncogene, referred to RET/PTC (the rearranged during transfection/ papillary thyroid carcinoma tyrosine kinase) fusion genes, is one of the best-known mutations in papillary thyroid carcinoma (PTC) [1]. RET/PTC is identified as a specific genetic event in patients with PTC, which forms the basis of differential diagnosis and novel therapeutic approaches to this disease [2]. However, the prevalence rate of the major RET/PTC subtypes in different ethnicities and their correlation with the clinicopathologic features of
PTC remains controversial and as yet are not routinely investigated in clinical practice.

The receptor tyrosine kinase RET plays a critical role in cell differentiation and proliferation, which is required for normal development of several tissues, especially in early embryogenesis [3]. In 1985, Takahashi and colleagues initially reported $R E T$ as a proto-oncogene that can be activated by interchromosomal rearrangement [4]. Subsequent studies demonstrated more than a dozen different forms of RET rearrangement, of which RET/PTC1 and RET/PTC3 are the most common, resulting from the fusion of RET with $H 4$ and of RET with RFG/ELEI 
respectively [5]. However, their prevalence rates in PTC exhibit significant geographic variation, ranging from $0 \%$ to $86.7 \%$ among studies $[6,7]$. As risk factors such as sex, age, and radiation exposure are related to PTC pathogenesis, scientists have focused on searching for the factors that increase RET/PTCrearrangement risk. Accordingly, several studies have detected RET/PTC rearrangements more frequently in PTC in children than in adults $[8,9]$. A relatively high prevalence of $R E T / P T C$ rearrangements was reported in radiation-induced PTC [10]. In addition, ethnicity and demographic characteristics may also influence the frequency of RET/PTC rearrangement [11-13]. To date, numerous relevant studies have been published but with divergent results.

In this study, we aimed to identify an enriched population who were more likely to occur RET/PTC1 and RET/PTC3 fusion genes and to provide more useful information on candidate selection for PTC prevention, diagnosis, and treatment. Therefore, we performed this meta-analysis to investigate the association between the presence/absence of RET/PTC1 or RET/PTC3 and radiation exposure, sex, age, and ethnicity.

\section{RESULTS}

\section{Basic characteristics of enrolled studies}

The article selection flowchart is depicted in Figure 1. A total 2014 records were obtained by searching the PubMed, Web of Science, and Embase databases. After removing duplicates, we found 1206 potentially relevant records. By reviewing titles, abstracts, and full texts according to the inclusion and exclusion criteria, 1168 articles were excluded because they were not relevant, involved in vitro or animal experiments, were reviews or meeting abstracts, contained data covered by other studies, had no raw data, etc. Eventually, 38 full-text articles, which consisted of 2395 PTC cases, met our inclusion criteria and were included in the final meta-analysis [6-10, 14-47].

The main characteristics of the studies included in this meta-analysis are summarized in Table 1 . The status of the RET/PTC fusion gene in the original studies were detected by PCR combined with reverse transcription (RT), Southern Blot or fluorescence in situ hybridization (FISH). The included studies involved populations from different geographical regions, namely Asia, Europe, and America; therefore, we divided the studies into Asian and Western subgroups.

We also summarized the positive rates of RET/PTC from each original study (Table 2). The overall prevalence of RET/PTC was relatively higher in the Western populations (42.19\%) than in the Asian populations (36.73\%). A similar tendency was observed for the RET/PTC1 subtype, whereas the Asian populations demonstrated a higher positive rate for the RET/PTC3 subtype (Asian vs. Western populations: $26.50 \%$ vs. $17.05 \%$ ). In the Asian studies, the positive rates of RET/PTC3 in the studies by Lam et al. [16] and Rao et al. [7] were up to $85.71 \%$ and $86.67 \%$, respectively, while another six studies reported a much lower incidence of RET/PTC3 that ranged from $0 \%$ to $20.79 \%$ [9, 14, 20-23].

\section{Association between radiation exposure and RET/PTC fusion genes}

As radiation exposure is the best-known risk factor for PTC, we initially investigated the effect of radiation on RET/PTC rearrangement (Table 3). Fourteen studies investigated the distribution difference of radiation exposure between RET/PTC-positive and -negative patients with PTC. When the RET/PTC1 and RET/PTC3 subtypes were combined, radiation exposure conferred increased overall risk for $R E T / P T C$ development $(\mathrm{OR}=$ 2.82, 95\%CI: $1.38-5.78 ; \mathrm{P}=0.005$, Figure 2) and there was moderate heterogeneity $\left(\mathrm{I}^{2}=74 \%, \mathrm{P}_{\text {het }}<0.001\right)$. Stratified analysis according to geographical region decreased the heterogeneity slightly, and increased risk for $R E T / P T C$ rearrangement persisted in the Western subpopulation, demonstrating an increased OR of 3.97 (95\%CI: 2.03-7.75; P $<0.001)$.

When the RET/PTC1 and RET/PTC3 subtypes were considered separately, radiation exposure conferred significantly higher risk for RET/PTC3 rearrangement (OR $=8.30$, 95\% CI: 4.32-15.96; P $<0.001$, Figure 3) but not for $R E T / P T C 1$ rearrangement. This association was only evident in the Western subpopulation. Separate pooled analysis for the RET/PTC1 and RET/PTC3 subtypes was not performed for the Asian subpopulation because three original studies involving this population investigated the combined status of RET/PTC1 and RET/PTC3, and the data could not be extracted separately $[9,15,22]$. Only one study with a small sample in an Asian country reported the RET/PTC1 and RET/PTC3 fusion gene data separately [21]. There was significant inter-study heterogeneity in the RET/PTC1 analysis but not in the RET/PTC3 analysis.

\section{Association between RET/PTC fusion genes and age}

Different age effects have been observed in the development of PTC, and we therefore explored whether young age affected the penetrance of the RET/PTC fusion genes in children and adolescents (Table 4). In this meta-analysis, age $<18$ years was considered young, i.e., children and adolescents. In the combined analysis of the RET/PTC1 and RET/PTC3 subtypes, no association was observed between age and $R E T / P T C$ rearrangement. In the separate analysis of the RET/PTC1 and RET/PTC3 subtypes, young people had nearly twofold greater risk for $R E T / P T C 3$ rearrangement (Figure 4) but penetrance of the RET/PTC1 fusion gene was not affected. When radiation exposure was also considered, young people in the subpopulation with radiation exposure had higher risk for developing RET/PTC3 
rearrangement as compared to adults with radiation exposure. These positive associations were performed in a fixed-effects model and had slight inter-study heterogeneity (all Phet $>0.10$ ).

\section{Association between RET/PTC fusion genes and sex}

Females are more likely to develop PTC, therefore we investigated whether female gender increases the chance of RET/PTC rearrangement in patients with PTC. As suggested by the findings in Table 5, sex was not statistically associated with RET/PTC status in the combined analysis. In subgroup analysis, a pooled analysis of 13 studies showed that female gender was associated with RET/PTC1 development in the subpopulation without radiation exposure. Female patients had 1.69-fold greater risk for RET/PTC1 rearrangement than male patients did (95\%CI: 1.04-2.74; P = 0.034, Figure 5). However, female gender did not appear to play a role in $R E T / P T C 3$ rearrangement (all, $\mathrm{P}>0.05$ ). Only slight inter-study heterogeneity was observed in all of the above analyses (all Phet $>0.10$ ).

\section{Heterogeneity testing and sensitivity analysis}

The inter-study heterogeneities in each comparison are presented in Tables 3-5. Pooled analyses for assessing the effect of radiation exposure and young age on the combined status of the RET/PTC1 and RET/PTC3 fusion genes demonstrated moderate heterogeneity. To explore the source of heterogeneity, subgroup analyses based on ethnicity and RET/PTC subtype were performed. Heterogeneity was decreased in the subgroup analysis and may be partly explained by the different ethnicities and RET/PTC subtypes (Tables 3 and 5).

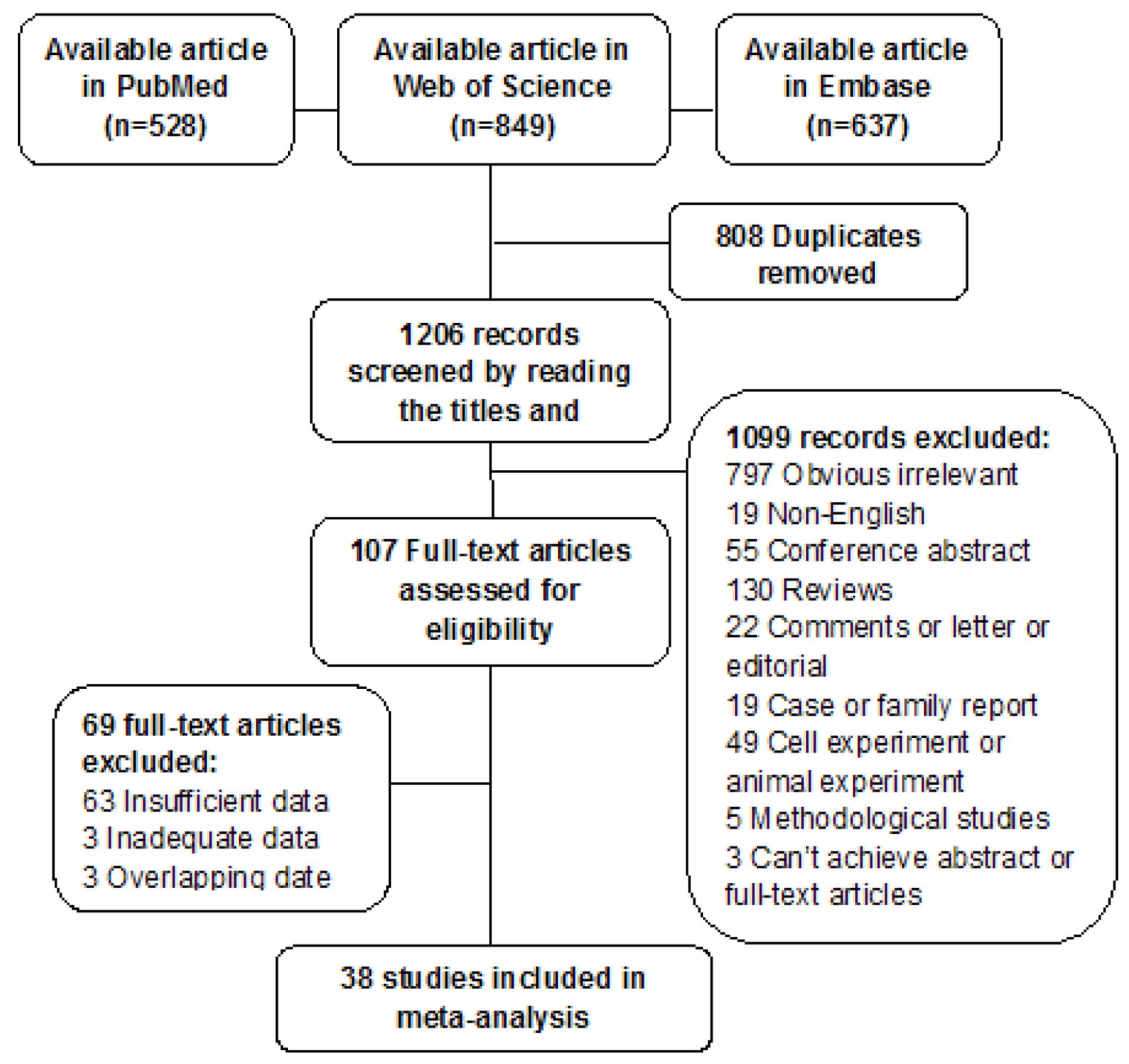

Figure 1: Flowchart of literature search and selection of studies. 
Table 1: Characteristics of studies included in the meta-analysis

\begin{tabular}{|c|c|c|c|c|c|c|}
\hline First author & $\begin{array}{c}\text { Year of } \\
\text { publication }\end{array}$ & Ethnicity & Region & $\begin{array}{l}\text { Method of } \\
\text { detection }\end{array}$ & Radiation & $\begin{array}{c}\text { No.of } \\
\text { patients }\end{array}$ \\
\hline Nikiforov et al & 1997 & $\begin{array}{l}\text { Belarussian, Los Angeles, } \\
\text { Cincinnati }\end{array}$ & Western & RT-PCR & Mixed & 55 \\
\hline Bounacer et al & 1997 & French & Western & RT-PCR & Mixed & 39 \\
\hline Motomura et al & 1998 & Japanese & Asian & RT-PCR & $\begin{array}{l}\text { Non- } \\
\text { radiation }\end{array}$ & 21 \\
\hline Smida et al & 1999 & Belarussian, German & Western & RT-PCR & Mixed & 83 \\
\hline Rabes et al & 2000 & Belarus, Russia, Ukrainian & Western & PCR & Radiation & 191 \\
\hline Elisei et al & 2001 & Belarus, Itaian & Western & PCR & Mixed & 89 \\
\hline Puxeddu et al & 2003 & Italian & Western & $\begin{array}{l}\text { RT-PCR, } \\
\text { Southern Blot }\end{array}$ & $\begin{array}{l}\text { Non- } \\
\text { radiation }\end{array}$ & 48 \\
\hline Rhoden et al & 2004 & American & Western & RT-PCR & NM & 25 \\
\hline Nakazawa et al & 2005 & Japanese & Asian & RT-PCR & $\begin{array}{l}\text { Non- } \\
\text { radiation }\end{array}$ & 169 \\
\hline Brzezianska et al & 2006 & Polish & Western & RT-PCR & NM & 33 \\
\hline Hamatani et al & 2008 & Japanese & Asian & RT-PCR & Mixed & 71 \\
\hline Tuttle et al & 2008 & Russian & Western & RT-PCR & Radiation & 76 \\
\hline Lam et al & 2002 & China, Hong Kong & Asian & RT-PCR & $\begin{array}{l}\text { Non- } \\
\text { radiation }\end{array}$ & 21 \\
\hline Detours et al & 2005 & Ukrainian & Western & RT-PCR & Mixed & 20 \\
\hline Lima et al & 2004 & Ukrainian & Western & RT-PCR & Mixed & 34 \\
\hline Penko et al & 2005 & American & Western & PCR & Mixed & 13 \\
\hline Romei et al & 2008 & Italian & Western & RT-PCR & $\begin{array}{l}\text { Non- } \\
\text { radiation }\end{array}$ & 70 \\
\hline Hieber et al & 2011 & Ukrainian & Western & FISH & Radiation & 22 \\
\hline Guerra et al & 2014 & Italian & Western & RT-PCR & NM & 72 \\
\hline Zou et al & 2014 & Saudi Arabian & Asian & RT-PCR & NM & 88 \\
\hline Chung et al & 1999 & Korean & Asian & RT-PCR & $\begin{array}{l}\text { Non- } \\
\text { radiation }\end{array}$ & 31 \\
\hline Powell et al & 2005 & Ukrainian & Western & PCR & Mixed & 35 \\
\hline Unger et al & 2004 & Ukrainian & Western & FISH & Radiation & 29 \\
\hline Wang et al & 2008 & Chinese & Asian & RT-PCR & $\begin{array}{l}\text { Non- } \\
\text { radiation }\end{array}$ & 126 \\
\hline Nikiforova et al & 2004 & Belorussian, Ukrainian & Western & PCR & Mixed & 137 \\
\hline Basolo et al & 2002 & Italian & Western & RT-PCR & NM & 91 \\
\hline Rao et al & 2014 & Indian & Asian & RT-PCR & $\begin{array}{l}\text { Non- } \\
\text { radiation }\end{array}$ & 30 \\
\hline Collins et al & 2002 & American & Western & IHC & Mixed & 64 \\
\hline Chung et al & 2004 & Korean & Asian & RT-PCR+IHC & $\begin{array}{l}\text { Non- } \\
\text { radiation }\end{array}$ & 22 \\
\hline Unger et al & 2006 & Ukrainian & Western & FISH & Radiation & $\begin{array}{c}13 \\
\text { (Continued) }\end{array}$ \\
\hline
\end{tabular}




\begin{tabular}{|c|c|c|c|c|c|c|}
\hline First author & $\begin{array}{c}\text { Year of } \\
\text { publication }\end{array}$ & Ethnicity & Region & $\begin{array}{l}\text { Method of } \\
\text { detection }\end{array}$ & Radiation & $\begin{array}{c}\text { No.of } \\
\text { patients }\end{array}$ \\
\hline Sadetzki et al & 2004 & Israelis & Asian & RT-PCR & Mixed & 49 \\
\hline Smyth et al & 2005 & Irish & Western & Taqman & NM & 34 \\
\hline Learoyd et al & 1998 & Australian, Swedish & Western & RT-PCR & Mixed & 50 \\
\hline Nakazawa et al & 2009 & Japanese & Asian & FISH+RT-PCR & $\begin{array}{l}\text { Non- } \\
\text { radiation }\end{array}$ & 14 \\
\hline $\begin{array}{l}\text { Di Cristofaro } \\
\text { et al }\end{array}$ & 2005 & Ukrainian, French & Western & RT-PCR & Mixed & 50 \\
\hline Erdogan & 2008 & Turkish & Asian & RT-PCR & $\begin{array}{l}\text { Non- } \\
\text { radiation }\end{array}$ & 101 \\
\hline Fenton et al & 2000 & American & Western & PCR & $\begin{array}{l}\text { Non- } \\
\text { radiation }\end{array}$ & 33 \\
\hline Guerra et al & 2011 & Italian & Western & RT-PCR & NM & 50 \\
\hline Stanojevic et al & 2011 & Serbian & Western & PCR & $\begin{array}{l}\text { Non- } \\
\text { radiation }\end{array}$ & 266 \\
\hline
\end{tabular}

Table 2: Positive rates of RET/PTC1 and RET/PTC3 in each original study

\begin{tabular}{lcccccccc}
\hline First author & $\begin{array}{c}\text { Year of } \\
\text { publication }\end{array}$ & $\begin{array}{c}\text { No. of } \\
\text { PTC } \\
\text { cases }\end{array}$ & $\begin{array}{c}\text { Freq. of } \\
\text { RET/ } \\
\text { PTC1 } \\
\text { and 3 }\end{array}$ & $\begin{array}{c}\text { RET/ } \\
\text { PTC1 } \\
\text { and 3(\%) }\end{array}$ & $\begin{array}{c}\text { Freq. of } \\
\text { RET/ } \\
\text { PTC1 }\end{array}$ & $\begin{array}{c}\text { RET/ } \\
\text { PTC1(\%) }\end{array}$ & $\begin{array}{c}\text { Freq. of } \\
\text { RET/ } \\
\text { PTC3 }\end{array}$ & $\begin{array}{c}\text { RET/ } \\
\text { PTC3(\%) }\end{array}$ \\
\hline For Asian studies & & & & $\mathbf{3 6 . 7 3 \%}$ & & $\mathbf{2 1 . 0 6 \%}$ & $\mathbf{2 6 . 5 0 \%}$ \\
Motomura et al & 1998 & 21 & 7 & $33.33 \%$ & 5 & $23.81 \%$ & 2 & $9.52 \%$ \\
Nakazawa et al & 2005 & 169 & 48 & $28.40 \%$ & 43 & $25.44 \%$ & 8 & $4.73 \%$ \\
Hamatani et al & 2008 & 71 & 12 & $16.90 \%$ & & & & \\
Lam et al & 2002 & 21 & 18 & $85.71 \%$ & & & 18 & $85.71 \%$ \\
Zou et al & 2014 & 88 & 12 & $13.64 \%$ & 12 & $13.64 \%$ & & \\
Chung et al & 1999 & 31 & 4 & $12.90 \%$ & & & & \\
Wang et al & 2008 & 126 & 18 & $14.29 \%$ & & & & \\
Rao et al & 2014 & 30 & 26 & $86.67 \%$ & 0 & $0.00 \%$ & 26 & $86.67 \%$ \\
Chung et al & 2004 & 22 & 2 & $9.09 \%$ & 1 & $4.55 \%$ & 1 & $4.55 \%$ \\
Sadetzki et al & 2004 & 49 & 22 & $44.90 \%$ & 20 & $40.82 \%$ & 0 & $0.00 \%$ \\
Nakazawa et al & 2009 & 14 & 4 & $28.57 \%$ & 4 & $28.57 \%$ & 0 & $0.00 \%$ \\
Erdogan & 2008 & 101 & 67 & $66.34 \%$ & 32 & $31.68 \%$ & 21 & $20.79 \%$ \\
For Western studies & & & & $\mathbf{4 2 . 1 9 \%}$ & & $\mathbf{2 5 . 2 5 \%}$ & & $\mathbf{1 7 . 0 5 \%}$ \\
Nikiforov et al & 1997 & 55 & 40 & $72.73 \%$ & 14 & $25.45 \%$ & 25 & $45.45 \%$ \\
Bounacer et al & 1997 & 39 & 18 & $46.15 \%$ & 15 & $38.46 \%$ & 5 & $12.82 \%$ \\
Smida et al & 1999 & 83 & 39 & $46.99 \%$ & 26 & $31.33 \%$ & 13 & $15.66 \%$ \\
Rabes et al & 2000 & 191 & 86 & $45.03 \%$ & 48 & $25.13 \%$ & 38 & $19.90 \%$ \\
Elisei et al & 2001 & 89 & 40 & $44.94 \%$ & 18 & $20.22 \%$ & 26 & $29.21 \%$ \\
Puxeddu et al & 2003 & 48 & 13 & $27.08 \%$ & 8 & $16.67 \%$ & 5 & $10.42 \%$ \\
& & & & & & & & $($ Continued)
\end{tabular}




\begin{tabular}{lcccccccc}
\hline First author & $\begin{array}{c}\text { Year of } \\
\text { publication }\end{array}$ & $\begin{array}{c}\text { No. of } \\
\text { PTC } \\
\text { cases }\end{array}$ & $\begin{array}{c}\text { Freq. of } \\
\text { RET/ } \\
\text { PTC1 } \\
\text { and 3 }\end{array}$ & $\begin{array}{c}\text { RET/ } \\
\text { PTC1 } \\
\text { and 3(\%) }\end{array}$ & $\begin{array}{c}\text { Freq. of } \\
\text { RET/ } \\
\text { PTC1 }\end{array}$ & $\begin{array}{c}\text { RET/ } \\
\text { PTC1(\%) }\end{array}$ & $\begin{array}{c}\text { Freq. of } \\
\text { RET/ } \\
\text { PTC3 }\end{array}$ & $\begin{array}{c}\text { RET/ } \\
\text { PTC3(\%) }\end{array}$ \\
\hline Rhoden et al & 2004 & 25 & 18 & $72.00 \%$ & 18 & $72.00 \%$ & 5 & $20.00 \%$ \\
Brzezianska et al & 2006 & 33 & 7 & $21.21 \%$ & & & & \\
Tuttle et al & 2008 & 76 & 13 & $17.11 \%$ & 11 & $14.47 \%$ & 5 & $6.58 \%$ \\
Detours et al & 2005 & 20 & 7 & $35.00 \%$ & 1 & $5.00 \%$ & 2 & $10.00 \%$ \\
Lima et al & 2004 & 34 & 14 & $41.18 \%$ & & & & \\
Penko et al & 2005 & 13 & 7 & $53.85 \%$ & 5 & $38.46 \%$ & 2 & $15.38 \%$ \\
Romei et al & 2008 & & & & 13 & $18.57 \%$ & 12 & $17.14 \%$ \\
Hieber et al & 2011 & 22 & 17 & $77.27 \%$ & & & & \\
Guerra et al & 2014 & 72 & 12 & $16.67 \%$ & & & & \\
Powell et al & 2005 & 35 & 16 & $45.71 \%$ & & & & \\
Unger et al & 2004 & 29 & 5 & $17.24 \%$ & 2 & $6.90 \%$ & 3 & $10.34 \%$ \\
Nikiforova et al & 2004 & 137 & 48 & $35.04 \%$ & 16 & $11.68 \%$ & 32 & $23.36 \%$ \\
Basolo et al & 2002 & 91 & 28 & $30.77 \%$ & 6 & $6.59 \%$ & 22 & $24.18 \%$ \\
Collins et al & 2002 & 64 & 44 & $68.75 \%$ & & & & \\
Unger et al & 2006 & 13 & 10 & $76.92 \%$ & & & & \\
Smyth et al & 2005 & 34 & 13 & $38.24 \%$ & 10 & $29.41 \%$ & 3 & $8.82 \%$ \\
Learoyd et al & 1998 & 50 & 4 & $8.00 \%$ & 4 & $8.00 \%$ & 0 & $0.00 \%$ \\
Di Cristofaro et al & 2005 & 50 & 30 & $60.00 \%$ & 26 & $52.00 \%$ & 13 & $26.00 \%$ \\
Fenton et al & 2000 & 33 & 14 & $42.42 \%$ & 11 & $33.33 \%$ & 3 & $9.09 \%$ \\
Guerra et al & 2011 & 50 & 18 & $36.00 \%$ & & & & \\
Stanojevic et al & 2011 & 266 & 55 & $20.68 \%$ & 42 & $15.79 \%$ & 13 & $4.89 \%$ \\
\hline
\end{tabular}

Sensitivity analysis was also conducted to assess the influence of individual studies on the overall risk of $R E T / P T C$ rearrangement by excluding any single study in turn and recalculating the pooled ORs and $95 \% \mathrm{CI}$. For the effect of radiation on RET/PTC rearrangement, Sadetzki et al. [21], Nakazawa et al. [22], and Bounacer et al. [24] reported greater differences in the risk estimates compared with other studies in the sensitivity analysis. Sensitivity analysis excluding the three studies generated a similar pooled OR of $3.30(95 \% \mathrm{CI}$ : $1.96-5.54, \mathrm{P}<0.001 ; \mathrm{I}^{2}=32.1 \%, \mathrm{P}_{\text {het }}=0.142$ ) among homogeneous studies. For the effect of young age on $R E T / P T C$ rearrangement, the outlier studies appeared to be the studies of Smida et al. (1999)[8] and Hieber et al. (2011)[35]. After removing the two studies, the heterogeneity was no longer significant $\left(\mathrm{I}^{2}=34.0 \%\right.$, $\left.\mathrm{P}_{\text {het }}=0.181\right)$, and similar estimates $(\mathrm{OR}=1.10 \mathrm{vs}$. 1.53) were generated before and after these data were removed, indicating the relatively high stability of the results.

\section{Publication bias}

Begg's test and Egger's test were performed to quantitatively evaluate the publication bias of the studies; the results are listed in Table 6 . No significant publication bias was observed in all comparisons (all, $\mathrm{P}>0.10)$.

\section{DISCUSSION}

Previous study results on the relationship between PTC-related risk factors and RET/PTC rearrangement were controversial. To our knowledge, this is the first meta-analysis evaluating the effect of radiation exposure, female gender, and young age on RET/PTC rearrangement. By performing the present meta-analysis, we found that radiation exposure contributed to increased risk of RET/PTC rearrangement, especially for the RET/PTC3 subtype. Young age was also associated with higher prevalence of RET/PTC3, and this association was more 
Table 3: Meta-analysis results for association between $R E T / P T C$ fusion genes and radiation exposure in patients with PTC

\begin{tabular}{lccccccc}
\hline $\begin{array}{l}\text { Radiation exposure vs. } \\
\text { non-radiation exposure }\end{array}$ & $\begin{array}{c}\text { No. of } \\
\text { studies }\end{array}$ & $\begin{array}{c}\text { No. of } \\
\text { cases/ } \\
\text { controls }\end{array}$ & OR(95\%CI) & P value & Model $^{2}$ & I $^{2}$ & Phet $^{\text {a }}$ \\
\hline
\end{tabular}

For RET/PTC1 and 3

\begin{tabular}{|c|c|c|c|c|c|c|c|}
\hline All & 14 & $537 / 388$ & $2.82(1.38,5.78)$ & 0.005 & Random & $74 \%$ & $<0.001$ \\
\hline \multicolumn{8}{|l|}{ Region } \\
\hline Asian & 4 & $232 / 71$ & $0.88(0.26,2.93)$ & 0.833 & Random & $56 \%$ & 0.077 \\
\hline Western & 10 & $305 / 317$ & $3.97(2.03,7.75)$ & $<0.001$ & Random & $59 \%$ & $<0.001$ \\
\hline \multicolumn{8}{|c|}{ For RET/PTC1 } \\
\hline All & 9 & $285 / 287$ & $1.86(0.66,5.28)$ & 0.243 & Random & $76.00 \%$ & $<0.001$ \\
\hline \multicolumn{8}{|l|}{ Region } \\
\hline Asian & 1 & $37 / 12$ & $0.24(0.06,0.96)$ & 0.043 & Random & l & I \\
\hline Western & 8 & $248 / 275$ & $2.46(0.83,7.27)$ & 0.104 & Random & $74.10 \%$ & $<0.001$ \\
\hline \multicolumn{8}{|c|}{ For RET/PTC3 } \\
\hline $\mathrm{All}^{\mathrm{b}}$ & 8 & $243 / 240$ & $8.30(4.32,15.96)$ & $<0.001$ & Fixed & $0.00 \%$ & 0.980 \\
\hline \multicolumn{8}{|l|}{ Region } \\
\hline Asian & l & l & l & l & I & l & l \\
\hline Western & 8 & $243 / 240$ & $8.30(4.32,15.96)$ & $<0.001$ & Fixed & $0.00 \%$ & 0.980 \\
\hline
\end{tabular}

a, P-value for heterogeneity test;

b, Data from Sadetzki et al. [21] and Learoyd et al. [6] showed that the RET/PTC3 gene prevalence was $100 \%$ in both the groups with and without radiation exposure and that the OR and standard error could not be estimated; therefore, these studies were excluded. The statistically significant results are highlighted in bold.

significant in the subpopulation exposed to radiation. Our pooled estimate also demonstrated an association between female gender and higher prevalence of the RET/PTC1 subtype in the subpopulation that had not been exposed to radiation. These results identify an enriched population of RET/PTC fusion genes in patients with PTC and provide novel insights into the utility of RET/PTC rearrangement in the differential diagnosis of suspicious PTC.

Exposure to ionizing radiation is a well-known risk factor for thyroid cancer, particularly for papillary carcinoma $[48,49]$. Therefore, it is likely that radiation exposure may also be a causative factor for RET/PTC rearrangement. Our pooled estimates provide clear evidence that radiation exposure could be responsible for the difference in $R E T / P T C 3$ prevalence between sporadic and radiation-associated tumors, whereas the rate of $R E T / P T C 1$ prevalence was similar between the two groups. The corresponding pooled OR for RET/PTC3 was up to 8.30 , and this association was evident in the Western populations. However, we could not derive a negative or null association in the Asian population because of a lack of original studies from the Asian region. There are valid reasons to believe that there is a causative link between radiation exposure and $R E T / P T C$ rearrangements. For example, Nikiforov et al. reported much higher RET/PTC3 prevalence in post-Chernobyl PTC than in subjects without radiation exposure [10]. In addition, RET/PTC rearrangement, predominantly $R E T / P T C 3$, in thyroid cells, can be induced by ionizing radiation [50]. This may be linked to the particular effectiveness of radiation in causing double-strand breaks, which would be the direct cause of RET rearrangement $[50,51]$. This mechanism may partially explain the association between radiation exposure and RET/PTC rearrangement in thyroid cancer.

The data synthesis in the present meta-analysis also demonstrated increased risk of RET/PTC 3 in PTC in young people. Our observations further indicate that young patients who exposed to radiation have higher RET/PTC3 risk than young patients who have not been exposed to radiation. Original studies have shown that RET/PTC3 is more common in children and adolescents compared to adults $[8,9]$. When the radiation exposure effect was considered in young people, RET/PTC3 was indicated as the most common form of rearrangement in radiation-associated childhood PTC $[8,10,25,52]$. As the thyroid is very sensitive to radiation, the thyroid of young people might be more vulnerable to 


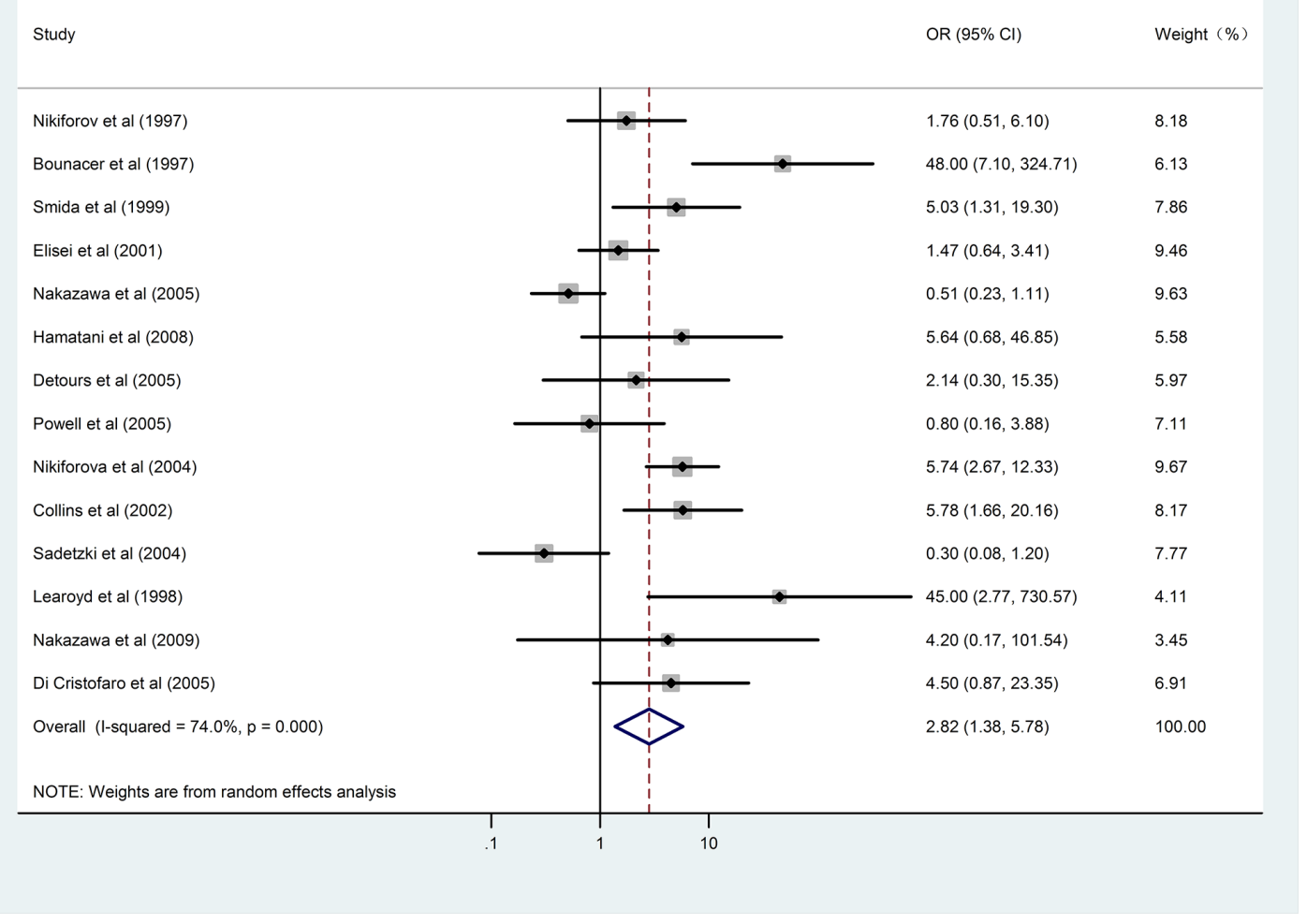

Figure 2: Results of the association between RET/PTC1 and RET/PTC3 fusion genes and radiation exposure in patients with PTC.

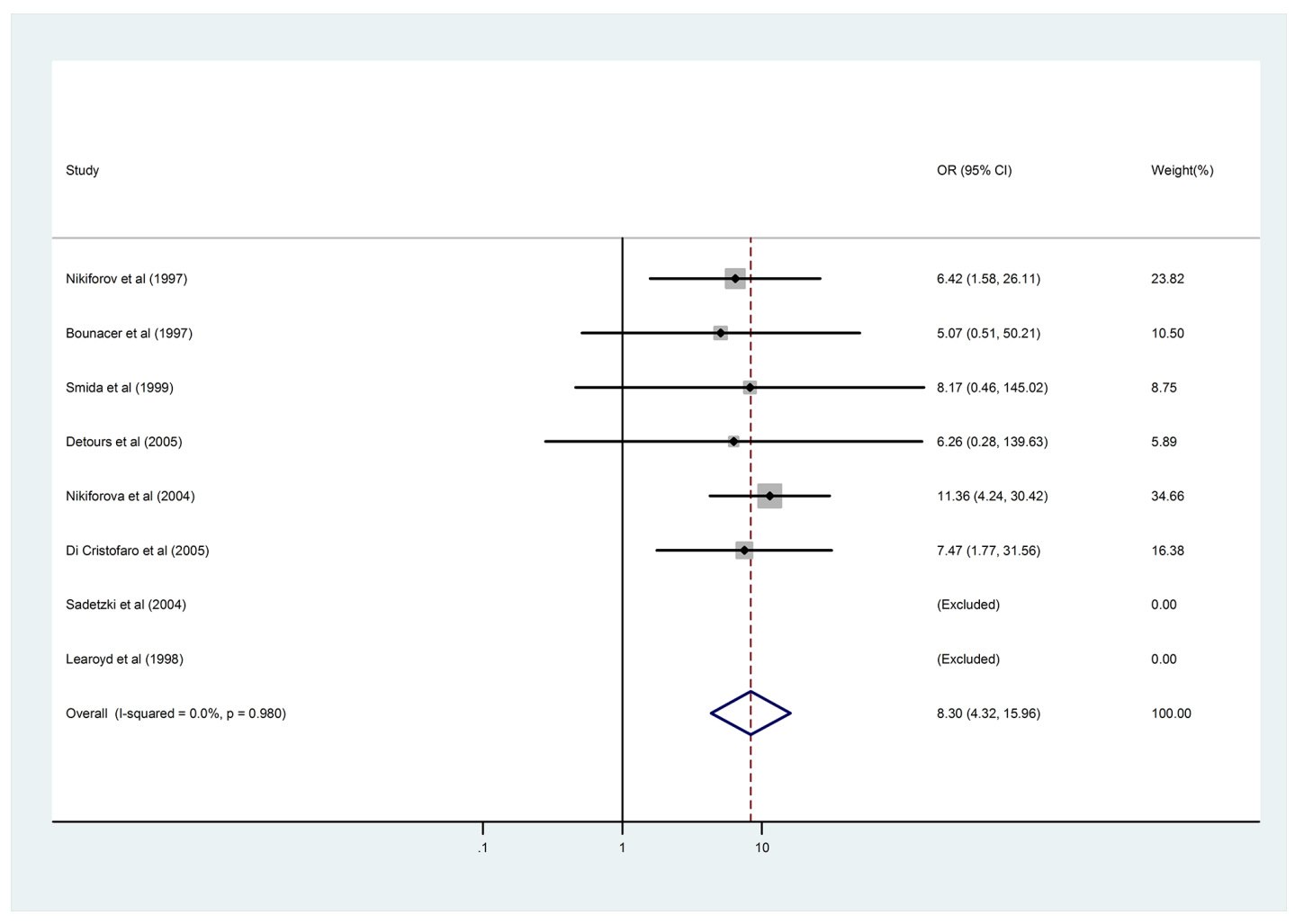

Figure 3: Results of the association between RET/PTC3 fusion gene and radiation exposure in patients with PTC. 
Table 4: Meta-analysis results for association between $R E T / P T C$ fusion genes and age in patients with PTC

\begin{tabular}{|c|c|c|c|c|c|c|c|}
\hline Young people vs. adult & $\begin{array}{l}\text { No. of } \\
\text { studies }\end{array}$ & $\begin{array}{c}\text { No. of } \\
\text { cases/ } \\
\text { controls }\end{array}$ & OR(95\%CI) & P value & Model & $\mathbf{I}^{2}$ & Phet $^{\mathrm{a}}$ \\
\hline \multicolumn{8}{|l|}{ For RET/PTC1 and 3} \\
\hline All & 8 & $187 / 332$ & $1.10(0.56,2.16)$ & 0.783 & Random & $51.50 \%$ & 0.044 \\
\hline \multicolumn{8}{|l|}{ Region } \\
\hline Asian & 2 & $41 / 149$ & $1.76(0.84,3.69)$ & 0.133 & Fixed & $4.30 \%$ & 0.307 \\
\hline Western & 6 & $146 / 183$ & $0.98(0.41,2.31)$ & 0.956 & Random & $54.50 \%$ & 0.052 \\
\hline \multicolumn{8}{|l|}{ Radiation } \\
\hline Radiation exposure & 6 & $116 / 122$ & $0.88(0.48,1.62)$ & 0.682 & Fixed & $41.50 \%$ & 0.129 \\
\hline Non-radiation exposure & 5 & $71 / 200$ & $1.46(0.81,2.65)$ & 0.212 & Fixed & $33.90 \%$ & 0.195 \\
\hline \multicolumn{8}{|l|}{ For RET/PTC1 } \\
\hline All & 6 & $172 / 286$ & $0.98(0.60,1.58)$ & 0.921 & Fixed & $7.20 \%$ & 0.370 \\
\hline \multicolumn{8}{|l|}{ Region } \\
\hline Asian & 2 & $41 / 149$ & $1.33(0.61,2.91)$ & 0.476 & Fixed & $0.00 \%$ & 0.466 \\
\hline Western & 4 & $131 / 137$ & $0.81(0.44,1.50)$ & 0.507 & Fixed & $21.40 \%$ & 0.282 \\
\hline \multicolumn{8}{|l|}{ Radiation } \\
\hline Radiation exposure & 5 & $107 / 109$ & $0.52(0.26,1.05)$ & 0.070 & Fixed & $49.30 \%$ & 0.096 \\
\hline Non-radiation exposure & 5 & $71 / 200$ & $1.47(0.76,2.86)$ & 0.250 & Fixed & $0.00 \%$ & 0.574 \\
\hline \multicolumn{8}{|l|}{ For RET/PTC3 } \\
\hline All & 7 & $179 / 318$ & 2.03(1.14,3.62) & 0.017 & Fixed & $46.70 \%$ & 0.081 \\
\hline \multicolumn{8}{|l|}{ Region } \\
\hline Asian & 2 & $42 / 148$ & $3.23(0.87,12.00)$ & 0.080 & Fixed & $7.20 \%$ & 0.299 \\
\hline Western & 5 & $137 / 170$ & $1.84(0.97,3.50)$ & 0.206 & Random & $50.1 \% \%$ & 0.091 \\
\hline \multicolumn{8}{|l|}{ Radiation } \\
\hline Radiation exposure & 5 & $107 / 109$ & $2.35(1.01,5.49)$ & 0.048 & Fixed & $0.00 \%$ & 0.574 \\
\hline Non-radiation exposure & 5 & $72 / 199$ & $1.68(0.28,10.01)$ & 0.570 & Random & $67.00 \%$ & 0.028 \\
\hline
\end{tabular}

a, P-value for heterogeneity test. The statistically significant results are highlighted in bold.

radiation than that of adults, which may result in higher $R E T / P T C$ prevalence in young people [53]. Nevertheless, it is important to consider that the statistical power in each original study may be partly determined by the cutoff value of age, such as age at diagnosis and age at exposure to radiation. When the cutoff age varies, the issue of the impact of patient age on RET/PTC rearrangement remains inconclusive, which would require further validation. By setting a cutoff age of 18 years in this meta-analysis, the corresponding results may indicate the relatively low defense ability of children against pathogenic factors.

Concerning the impact of sex, we observed that the association between female gender and increased RET/PTC1 risk was more significant in patients who had not been exposed to radiation. For unknown reasons, thyroid cancer is three times more prevalent in women than in men [54]. One possible explanation for this gender disparity is the hormonal differences between men and women. It has been documented that chromosome breaks and sister chromatid exchanges are elevated in women who are pregnant or taking oral contraceptives [55]. There is also evidence supporting the premise that $R E T / P T C$ is an estrogen-dependent gene required for breast cancer cell growth [56]. The above evidence suggests that some inherent differences render females more susceptible to RET rearrangements.

Nevertheless, this study has some limitations. First, although we included all available relevant articles in this metaanalysis, the sample sizes remain insufficiently large. Second, most studies in relation to the association between radiation exposure and RET/PTC3 were from the Western countries, 


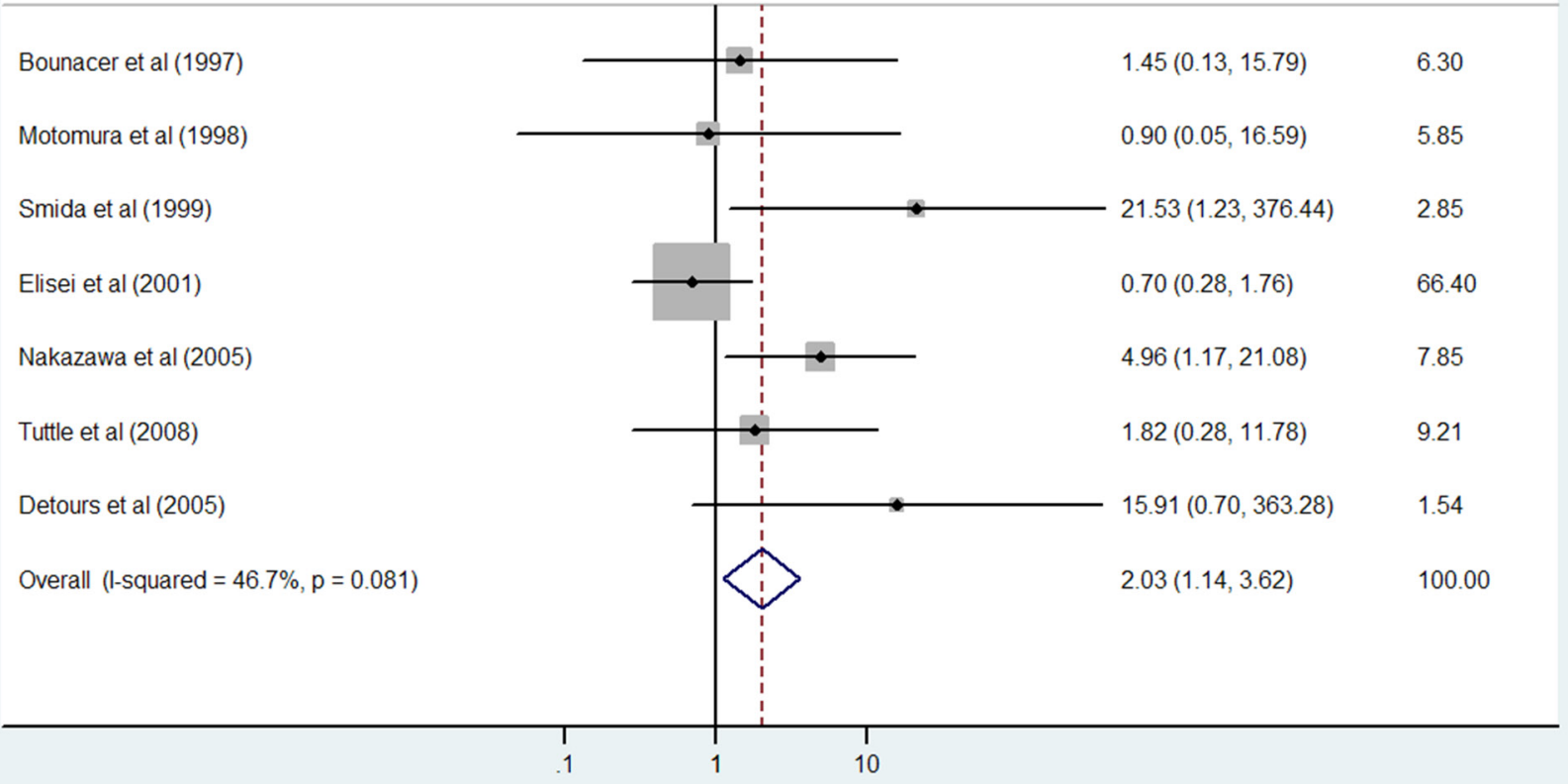

Figure 4: Results of the association between RET/PTC3 fusion gene and young age in patients with PTC.

thus the generalizability of our conclusions is limited. In the future, more studies are needed to confirm this association in Asian regions. Third, only two common RET/PTC subtypes, RET/PTC1 and RET/PTC3, were considered in this study, mainly due to the limitation of current laboratory techniques for simultaneously detecting all RET/PTC subtypes.

In conclusion, both radiation exposure and young age, i.e., age $<18$ years, are associated with increased risk of RET/PTC3 rearrangement. In addition, female gender is associated with higher prevalence of the RET/PTC1 subtype in the subpopulation not exposed to radiation. We suggest that RET/PTC status in combination with radiation exposure, age, and sex should be considered when differential diagnoses are suggested for suspicious patients. Further large-scale studies concerning the relationship between radiation exposure and RET/PTC in the Asian population are required to confirm our meta-analysis results.

\section{MATERIALS AND METHODS}

\section{Search strategy}

We searched the PubMed, Web of Science, and Embase databases for all articles on the association between the RET/PTC fusion gene and PTC up to June
2015. The published date of available articles in this study was from 1959 to 2015. The keywords used for the search were "RET/PTC", "RET/PTC fusion gene", or "RET/PTC fusion oncoproteins" in combination with "Thyroid Cancer", "Thyroid Carcinoma", "Thyroid Neoplasms", or "Thyroid Papillary Carcinoma". The references of the articles acquired were also searched manually to broaden the search. When there was overlapping data, only the largest and most recent study was selected for this metaanalysis. If the data presented in an article were unclear, we contacted the author for specific raw data.

\section{Inclusion and exclusion criteria}

Eligible studies had to meet the following criteria: (1) the association between the RET/PTC fusion gene and the clinicopathological features of patients with PTC was explored; (2) PTC diagnosis was made according to the pathology results; (3) studies were full-text articles; and (4) there was sufficient data for estimating an odds ratio (OR) with a $95 \%$ confidence interval (CI). The exclusion criteria were: (1) duplicate publication; (2) article was an abstract, comment, review, conference proceeding, or editorial; (3) insufficient data were reported; and (4) study was not in English or Chinese. 
Table 5: Meta-analysis results for association between $R E T / P T C$ fusion genes and sex in patients with PTC

\begin{tabular}{|c|c|c|c|c|c|c|c|}
\hline Female vs. male & $\begin{array}{l}\text { No. of } \\
\text { studies }\end{array}$ & $\begin{array}{l}\text { No. of cases/ } \\
\text { controls }\end{array}$ & OR(95\%CI) & P value & Model & $\mathbf{I}^{2}$ & Phet \\
\hline \multicolumn{8}{|l|}{ For RET/PTC1 and 3} \\
\hline All & 27 & $1211 / 474$ & $1.04(0.81,1.33)$ & 0.775 & Fixed & $0.00 \%$ & 0.938 \\
\hline \multicolumn{8}{|l|}{ Region } \\
\hline Asian & 9 & $373 / 138$ & $1.42(0.81,2.49)$ & 0.216 & Fixed & $0.00 \%$ & 0.754 \\
\hline Western & 18 & $838 / 336$ & $0.95(0.72,1.27)$ & 0.747 & Fixed & $0.00 \%$ & 0.934 \\
\hline \multicolumn{8}{|l|}{ Radiation } \\
\hline Radiation exposure & 11 & $369 / 174$ & $0.94(0.63,1.41)$ & 0.760 & Fixed & $0.00 \%$ & 0.941 \\
\hline Non-radiation exposure & 17 & $721 / 258$ & $1.28(0.90,1.82)$ & 0.171 & Fixed & $7.20 \%$ & 0.370 \\
\hline \multicolumn{8}{|l|}{ For RET/PTC1 } \\
\hline All a & 16 & $832 / 324$ & $1.21(0.87,1.69)$ & 0.256 & Fixed & $0.00 \%$ & 0.857 \\
\hline \multicolumn{8}{|l|}{ Region } \\
\hline Asian & 5 & $213 / 62$ & $0.98(0.48,2.01)$ & 0.962 & Fixed & $0.00 \%$ & 0.604 \\
\hline Western & 11 & $619 / 261$ & $1.28(0.88,1.87)$ & 0.193 & Fixed & $0.00 \%$ & 0.796 \\
\hline \multicolumn{8}{|l|}{ Radiation } \\
\hline Radiation exposure & 4 & $185 / 104$ & $1.22(0.70,2.11)$ & 0.482 & Fixed & $0.00 \%$ & 0.892 \\
\hline Non-radiation exposure & 13 & $581 / 192$ & $1.69(1.04,2.74)$ & 0.034 & Fixed & $0.00 \%$ & 0.768 \\
\hline \multicolumn{8}{|l|}{ For RET/PTC3 } \\
\hline All,b & 17 & $785 / 304$ & $0.87(0.60,1.27)$ & 0.466 & Fixed & $0.00 \%$ & 0.625 \\
\hline \multicolumn{8}{|l|}{ Region } \\
\hline Asian & 5 & $155 / 40$ & $1.54(0.59,3.99)$ & 0.378 & Fixed & $0.00 \%$ & 0.763 \\
\hline Western & 11 & $619 / 261$ & $0.77(0.51,1.17)$ & 0.223 & Fixed & $0.00 \%$ & 0.527 \\
\hline \multicolumn{8}{|l|}{ Radiation } \\
\hline Radiation exposure & 4 & $185 / 104$ & $0.82(0.45,1.48)$ & 0.504 & Fixed & $0.00 \%$ & 0.903 \\
\hline Non-radiation exposure & 11 & $570 / 186$ & $1.06(0.60,1.87)$ & 0.847 & Fixed & $0.00 \%$ & 0.696 \\
\hline
\end{tabular}

a, P-value for heterogeneity test;

', Data from Rao et al. [7] and Detours et al. [31] showed that RET/PTC1 gene prevalence was $100 \%$ in both female and male groups and that the OR and standard error could not be estimated; therefore, these studies were excluded. The statistically significant results are highlighted in bold.

\section{Data extraction}

The following items were collected: first name of first author; year of publication; population of study; number of enrolled patients; frequency of RET/PTC fusion gene; detection method; whether study subjects were children or adults; and clinicopathological features (sex, age, radiation history, and ethnicity). The above information was carefully extracted by two independent investigators (Xuan $\mathrm{Su}$ and Zhaoqu Li). If the two investigators could not reach a consensus, the result was reviewed by a third investigator (Caiyun $\mathrm{He}$ ).

\section{Statistical analyses}

The strength of the association between RET/PTC and radiation exposure, age, and sex was estimated by OR and $95 \% \mathrm{CI}$. Two-sided $\mathrm{P}$-values were evaluated in this meta-analysis, and $\mathrm{P}<0.05$ was considered statistically significant. The chi-square-based $\mathrm{Q}$ test and $\mathrm{I}^{2}$ statistic were used to assess the statistical heterogeneity among studies. For the Q statistic, $\mathrm{P}<0.10$ was considered statistically significant for heterogeneity. When there was heterogeneity, a random-effects model based on the DerSimonian and Laird method was used to calculate the 


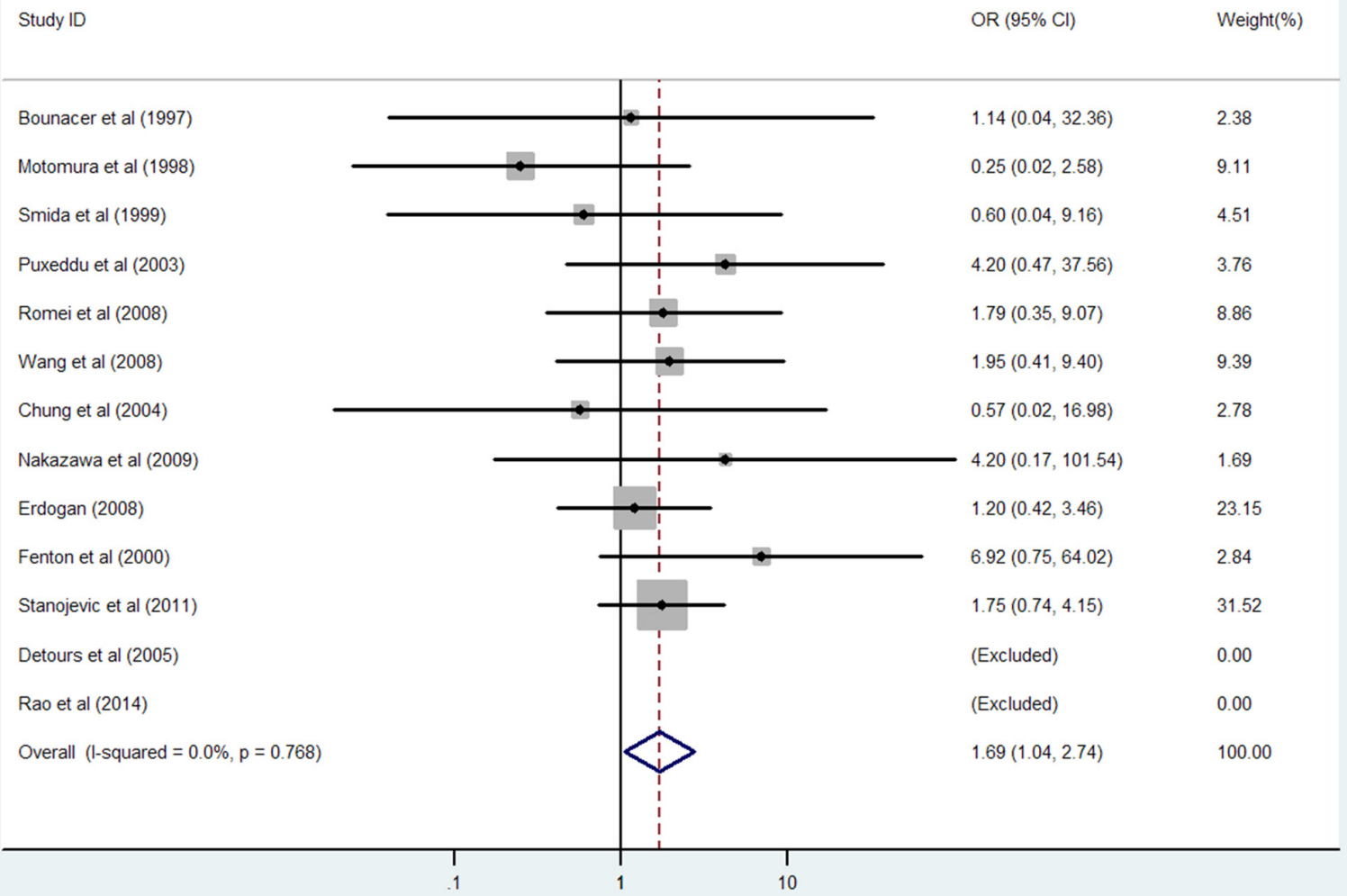

Figure 5 Results of the association between RET/PTC1 fusion gene and female gender in PTC patients without radiation exposure.

Table 6: Analysis for publication bias

\begin{tabular}{|c|c|c|c|c|}
\hline \multirow[t]{2}{*}{ Variable } & \multicolumn{2}{|c|}{ Begg's test } & \multicolumn{2}{|c|}{ Egger's test } \\
\hline & $\mathrm{z}$ value & Pvalue $^{\mathrm{a}}$ & t value & P value $^{\mathrm{a}}$ \\
\hline \multicolumn{5}{|l|}{ For RET/PTC 1 and 3} \\
\hline Radiation exposure vs. non-radiation exposure & 0.93 & 0.352 & 1.34 & 0.205 \\
\hline Female vs. male & 1.02 & 0.307 & 0.24 & 0.811 \\
\hline Children and adolecent vs. adult & -0.25 & 0.805 & 0.16 & 0.882 \\
\hline \multicolumn{5}{|l|}{ For RET/PTC1 } \\
\hline Radiation exposure vs. non-radiation exposure & 1.25 & 0.211 & 1.71 & 0.132 \\
\hline Female vs. male & 0.27 & 0.787 & 0.15 & 0.879 \\
\hline Children and adolecent vs. adult & -0.19 & 0.851 & 0.39 & 0.715 \\
\hline \multicolumn{5}{|l|}{ For RET/PTC3 } \\
\hline Radiation exposure vs. non-radiation exposure & -0.56 & 0.573 & -1.75 & 0.156 \\
\hline Female vs. male & 0.27 & 0.787 & 0.59 & 0.567 \\
\hline Children and adolecent vs. adult & 0.45 & 0.652 & 1.92 & 0.113 \\
\hline
\end{tabular}

a, $\mathrm{P}$ value $>0.1$ was considered as no publication bias. 
pooled OR of each study [57]; otherwise, a fixed-effects model based on the Mantel-Haenszel method was used [58]. Publication bias was examined using Begg's and Egger's tests [59, 60], where $\mathrm{P}<0.10$ was considered statistically significant. All analyses were performed using STATA 12.0. All tests were two-sided and the significance level was set at 0.05 .

\section{ACKNOWLEDGMENTS AND FUNDING}

This study was supported by National Science Foundation (81272955) and Guangdong Province Natural Science Foundation (2014A020212100).

\section{CONFLICTS OF INTEREST}

None declared.

\section{REFERENCES}

1. Mulligan LM. RET revisited: expanding the oncogenic portfolio. Nat Rev Cancer. 2014; 14: 173-86.

2. Al-Humadi H, Zarros A, Al-Saigh R, and Liapi C. Genetic basis and gene therapy trials for thyroid cancer. Cancer Genomics Proteomics. 2010; 7: 31-49.

3. Tsuzuki T, Takahashi M, Asai N, Iwashita T, Matsuyama M, and Asai J. Spatial and temporal expression of the ret proto-oncogene product in embryonic, infant and adult rat tissues. Oncogene. 1995; 10: 191-8.

4. Takahashi M, Ritz J, and Cooper GM. Activation of a novel human transforming gene, ret, by DNA rearrangement. Cell. 1985; 42: 581-8.

5. Nikiforov YE. RET/PTC rearrangement in thyroid tumors. Endocr Pathol. 2002; 13: 3-16.

6. Learoyd DL, Messina M, Zedenius J, Guinea AI, Delbridge LW, and Robinson BG. RET/PTC and RET tyrosine kinase expression in adult papillary thyroid carcinomas. J Clin Endocrinol Metab. 1998; 83: 3631-5.

7. Rao PJ, Vardhini NV, Parvathi MV, Murthy PB, and Sudhakar G. Prevalence of RET/PTC1 and RET/PTC3 gene rearrangements in Chennai population and its correlation with clinical parameters. Tumour Biol. 2014; 35: 9539-48.

8. Smida J, Salassidis K, Hieber L, Zitzelsberger H, Kellerer AM, Demidchik EP, Negele T, Spelsberg F, Lengfelder E, Werner M, and Bauchinger M. Distinct frequency of ret rearrangements in papillary thyroid carcinomas of children and adults from Belarus. Int J Cancer. 1999; 80: 32-8.

9. Nakazawa T, Kondo T, Kobayashi Y, Takamura N, Murata S, Kameyama K, Muramatsu A, Ito K, Kobayashi M, and Katoh R. RET gene rearrangements (RET/PTC1 and RET/ PTC3) in papillary thyroid carcinomas from an iodine-rich country (Japan). Cancer. 2005; 104: 943-51.

10. Nikiforov YE, Rowland JM, Bove KE, MonforteMunoz H, and Fagin JA. Distinct pattern of ret oncogene rearrangements in morphological variants of radiationinduced and sporadic thyroid papillary carcinomas in children. Cancer Res. 1997; 57: 1690-4.

11. Wajjwalku W, Nakamura S, Hasegawa Y, Miyazaki K, Satoh Y, Funahashi H, Matsuyama M, and Takahashi M. Low frequency of rearrangements of the ret and trk protooncogenes in Japanese thyroid papillary carcinomas. Jpn J Cancer Res. 1992; 83: 671-5.

12. Bongarzone I, Fugazzola L, Vigneri P, Mariani L, Mondellini P, Pacini F, Basolo F, Pinchera A, Pilotti S, and Pierotti MA. Age-related activation of the tyrosine kinase receptor protooncogenes RET and NTRK1 in papillary thyroid carcinoma. J Clin Endocrinol Metab. 1996; 81: 2006-9.

13. Bongarzone I, Vigneri P, Mariani L, Collini P, Pilotti S, and Pierotti MA. RET/NTRK1 rearrangements in thyroid gland tumors of the papillary carcinoma family: correlation with clinicopathological features. Clin Cancer Res. 1998; 4: 223-8.

14. Motomura $\mathrm{T}$, Nikiforov $\mathrm{YE}$, Namba H, Ashizawa K, Nagataki S, Yamashita S, and Fagin JA. ret rearrangements in Japanese pediatric and adult papillary thyroid cancers. Thyroid. 1998; 8: 485-9.

15. Hamatani K, Eguchi H, Ito R, Mukai M, Takahashi K, Taga M, Imai K, Cologne J, Soda M, Arihiro K, Fujihara M, Abe $\mathrm{K}$, Hayashi T, et al. RET/PTC rearrangements preferentially occurred in papillary thyroid cancer among atomic bomb survivors exposed to high radiation dose. Cancer Res. 2008; 68: 7176-82.

16. Lam KY, Lo CY, and Leung PS. High prevalence of RET proto-oncogene activation (RET/PTC) in papillary thyroid carcinomas. Eur J Endocrinol. 2002; 147: 741-5.

17. Zou M, Baitei EY, Alzahrani AS, BinHumaid FS, Alkhafaji D, Al-Rijjal RA, Meyer BF, and Shi Y. Concomitant RAS, RET/PTC, or BRAF mutations in advanced stage of papillary thyroid carcinoma. Thyroid. 2014; 24: 1256-66.

18. Chung JH, Hahm JR, Min YK, Lee MS, Lee MK, Kim KW, Nam SJ, Yang JH, and Ree HJ. Detection of RET/ PTC oncogene rearrangements in Korean papillary thyroid carcinomas. Thyroid. 1999; 9: 1237-43.

19. Wang YL, Zhang RM, Luo ZW, Wu Y, Du X, Wang ZY, Zhu YX, Li DS, and Ji QH. High frequency of level II-V lymph node involvement in RET/PTC positive papillary thyroid carcinoma. Eur J Surg Oncol. 2008; 34: 77-81.

20. Chung KW, Chang MC, Noh DY, Oh SK, Choe KJ, and Youn YK. RET oncogene expression of papillary thyroid carcinoma in Korea. Surg Today. 2004; 34: 485-92.

21. Sadetzki S, Calderon-Margalit R, Modan B, Srivastava S, and Tuttle RM. Ret/PTC activation in benign and malignant thyroid tumors arising in a population exposed to low-dose external-beam irradiation in childhood. J Clin Endocrinol Metab. 2004; 89: 2281-9.

22. Nakazawa T, Murata S, Kondo T, Niu D, Mochizuki K, Kawasaki T, Yamane T, Nakamura N, and Katoh R. RET/ 
PTC rearrangements arising from a small population of papillary thyroid carcinoma cells, possible candidate for passenger mutation. Virchows Arch. 2009; 455: 35-41.

23. Erdogan M, Berdeli A, Karadeniz M, Ertan Y, Cetinkalp S, Saygili F, Tuncyurek M, Yilmaz C, Tuzun M, Kabalak T, Uluer H, and Ozgen AG. The prevalence of RET/ PTC mutations in papillary thyroid cancers in Turkish population and its relation between tumor histopathology and prognostic factors. Exp Clin Endocrinol Diabetes. 2008; 116: 225-30.

24. Bounacer A, Wicker R, Caillou B, Cailleux AF, Sarasin A, Schlumberger M, and Suarez HG. High prevalence of activating ret proto-oncogene rearrangements, in thyroid tumors from patients who had received external radiation. Oncogene. 1997; 15: 1263-73.

25. Rabes HM, Demidchik EP, Sidorow JD, Lengfelder E, Beimfohr C, Hoelzel D, and Klugbauer S. Pattern of radiation-induced RET and NTRK1 rearrangements in 191 post-chernobyl papillary thyroid carcinomas: biological, phenotypic, and clinical implications. Clin Cancer Res. 2000; 6: 1093-103.

26. Elisei R, Romei C, Vorontsova T, Cosci B, Veremeychik V, Kuchinskaya E, Basolo F, Demidchik EP, Miccoli P, Pinchera A, and Pacini F. RET/PTC rearrangements in thyroid nodules: studies in irradiated and not irradiated, malignant and benign thyroid lesions in children and adults. J Clin Endocrinol Metab. 2001; 86: 3211-6.

27. Puxeddu E, Moretti S, Giannico A, Martinelli M, Marino C, Avenia N, Cristofani R, Farabi R, Reboldi G, Ribacchi R, Pontecorvi A, and Santeusanio F. Ret/PTC activation does not influence clinical and pathological features of adult papillary thyroid carcinomas. Eur J Endocrinol. 2003; 148: 505-13.

28. Rhoden KJ, Johnson C, Brandao G, Howe JG, Smith BR, and Tallini G. Real-time quantitative RT-PCR identifies distinct c-RET, RET/PTC1 and RET/PTC3 expression patterns in papillary thyroid carcinoma. Lab Invest. 2004; 84: 1557-70.

29. Brzezianska E, Karbownik M, Migdalska-Sek M, Pastuszak-Lewandoska D, Wloch J, and Lewinski A. Molecular analysis of the RET and NTRK1 gene rearrangements in papillary thyroid carcinoma in the Polish population. Mutat Res. 2006; 599: 26-35.

30. Tuttle RM, Lukes Y, Onstad L, Lushnikov E, Abrosimov A, Troshin V, Tsyb A, Davis S, Kopecky KJ, and Francis G. ret/PTC activation is not associated with individual radiation dose estimates in a pilot study of neoplastic thyroid nodules arising in Russian children and adults exposed to Chernobyl fallout. Thyroid. 2008; 18: 839-46.

31. Detours V, Wattel S, Venet D, Hutsebaut N, Bogdanova T, Tronko MD, Dumont JE, Franc B, Thomas G, and Maenhaut C. Absence of a specific radiation signature in post-Chernobyl thyroid cancers. Br J Cancer. 2005; 92: $1545-52$.
32. Lima J, Trovisco V, Soares P, Maximo V, Magalhaes J, Salvatore G, Santoro M, Bogdanova T, Tronko M, Abrosimov A, Jeremiah S, Thomas G, Williams D, et al. BRAF mutations are not a major event in post-Chernobyl childhood thyroid carcinomas. J Clin Endocrinol Metab. 2004; 89: 4267-71.

33. Penko K, Livezey J, Fenton C, Patel A, Nicholson D, Flora M, Oakley K, Tuttle RM, and Francis G. BRAF mutations are uncommon in papillary thyroid cancer of young patients. Thyroid. 2005; 15: 320-5.

34. Romei C, Ciampi R, Faviana P, Agate L, Molinaro E, Bottici V, Basolo F, Miccoli P, Pacini F, Pinchera A, and Elisei R. BRAFV600E mutation, but not RET/PTC rearrangements, is correlated with a lower expression of both thyroperoxidase and sodium iodide symporter genes in papillary thyroid cancer. Endocr Relat Cancer. 2008; 15: 511-20.

35. Hieber L, Huber R, Bauer V, Schaffner Q, Braselmann $\mathrm{H}$, Thomas $\mathrm{G}$, Bogdanova $\mathrm{T}$, and Zitzelsberger $\mathrm{H}$. Chromosomal rearrangements in post-Chernobyl papillary thyroid carcinomas: evaluation by spectral karyotyping and automated interphase FISH. J Biomed Biotechnol. 2011; 2011: 693691.

36. Guerra A, Zeppa P, Bifulco M, and Vitale M. Concomitant BRAF(V600E) mutation and RET/PTC rearrangement is a frequent occurrence in papillary thyroid carcinoma. Thyroid. 2014; 24: 254-9.

37. Powell N, Jeremiah S, Morishita M, Dudley E, Bethel J, Bogdanova T, Tronko M, and Thomas G. Frequency of BRAF T1796A mutation in papillary thyroid carcinoma relates to age of patient at diagnosis and not to radiation exposure. J Pathol. 2005; 205: 558-64.

38. Unger K, Zitzelsberger H, Salvatore G, Santoro M, Bogdanova T, Braselmann H, Kastner P, Zurnadzhy L, Tronko N, Hutzler P, and Thomas G. Heterogeneity in the distribution of RET/PTC rearrangements within individual post-Chernobyl papillary thyroid carcinomas. J Clin Endocrinol Metab. 2004; 89: 4272-9.

39. Nikiforova MN, Ciampi R, Salvatore G, Santoro M, Gandhi M, Knauf JA, Thomas GA, Jeremiah S, Bogdanova TI, Tronko $\mathrm{MD}$, Fagin JA, and Nikiforov YE. Low prevalence of BRAF mutations in radiation-induced thyroid tumors in contrast to sporadic papillary carcinomas. Cancer Lett. 2004; 209: 1-6.

40. Basolo F, Giannini R, Monaco C, Melillo RM, Carlomagno F, Pancrazi M, Salvatore G, Chiappetta G, Pacini F, Elisei R, Miccoli P, Pinchera A, Fusco A, et al. Potent mitogenicity of the RET/PTC3 oncogene correlates with its prevalence in tall-cell variant of papillary thyroid carcinoma. Am J Pathol. 2002; 160: 247-54.

41. Collins BJ, Chiappetta G, Schneider AB, Santoro M, Pentimalli F, Fogelfeld L, Gierlowski T, Shore-Freedman E, Jaffe G, and Fusco A. RET expression in papillary thyroid cancer from patients irradiated in childhood for benign conditions. J Clin Endocrinol Metab. 2002; 87: 3941-6. 
42. Unger K, Zurnadzhy L, Walch A, Mall M, Bogdanova T, Braselmann H, Hieber L, Tronko N, Hutzler P, Jeremiah S, Thomas G, and Zitzelsberger H. RET rearrangements in postChernobyl papillary thyroid carcinomas with a short latency analysed by interphase FISH. Br J Cancer. 2006; 94: 1472-7.

43. Smyth P, Finn S, Cahill S, O'Regan E, Flavin R, O'Leary JJ, and Sheils O. ret/PTC and BRAF act as distinct molecular, time-dependant triggers in a sporadic Irish cohort of papillary thyroid carcinoma. Int J Surg Pathol. 2005; 13: 1-8.

44. Di Cristofaro J, Vasko V, Savchenko V, Cherenko S, Larin A, Ringel MD, Saji M, Marcy M, Henry JF, Carayon P, and De Micco C. ret/PTC1 and ret/PTC3 in thyroid tumors from Chernobyl liquidators: comparison with sporadic tumors from Ukrainian and French patients. Endocr Relat Cancer. 2005; 12: 173-83.

45. Fenton CL, Lukes Y, Nicholson D, Dinauer CA, Francis GL, and Tuttle RM. The ret/PTC mutations are common in sporadic papillary thyroid carcinoma of children and young adults. J Clin Endocrinol Metab. 2000; 85: 1170-5.

46. Guerra A, Sapio MR, Marotta V, Campanile E, Moretti MI, Deandrea M, Motta M, Limone PP, Fenzi G, Rossi G, and Vitale M. Prevalence of RET/PTC rearrangement in benign and malignant thyroid nodules and its clinical application. Endocr J. 2011; 58: 31-8.

47. Stanojevic B, Dzodic R, Saenko V, Milovanovic Z, Pupic G, Zivkovic O, Markovic I, Djurisic I, Buta M, Dimitrijevic B, Rogounovitch T, Mitsutake N, Mine M, et al. Mutational and clinico-pathological analysis of papillary thyroid carcinoma in Serbia. Endocr J. 2011; 58: 381-93.

48. Pellegriti G, Frasca F, Regalbuto C, Squatrito S, and Vigneri R. Worldwide increasing incidence of thyroid cancer: update on epidemiology and risk factors. J Cancer Epidemiol. 2013; 2013: 965212.

49. Vigneri R, Malandrino $\mathrm{P}$, and Vigneri $\mathrm{P}$. The changing epidemiology of thyroid cancer: why is incidence increasing? Curr Opin Oncol. 2015; 27: 1-7.
50. Evdokimova V, Gandhi M, Rayapureddi J, Stringer JR, and Nikiforov YE. Formation of carcinogenic chromosomal rearrangements in human thyroid cells after induction of double-strand DNA breaks by restriction endonucleases. Endocr Relat Cancer. 2012; 19: 271-81.

51. Winegar RA, Lutze LH, Rufer JT, and Morgan WF. Spectrum of mutations produced by specific types of restriction enzymeinduced double-strand breaks. Mutagenesis. 1992; 7: 439-45.

52. Zhu Z, Ciampi R, Nikiforova MN, Gandhi M, and Nikiforov YE. Prevalence of RET/PTC rearrangements in thyroid papillary carcinomas: effects of the detection methods and genetic heterogeneity. J Clin Endocrinol Metab. 2006; 91: 3603-10.

53. Hatch M, Ron E, Bouville A, Zablotska L, and Howe G. The Chernobyl disaster: cancer following the accident at the Chernobyl nuclear power plant. Epidemiol Rev. 2005; 27: 56-66.

54. Rahbari R, Zhang L, and Kebebew E. Thyroid cancer gender disparity. Future Oncol. 2010; 6: 1771-9.

55. Biri A, Civelek E, Karahalil B, and Sardas S. Assessment of DNA damage in women using oral contraceptives. Mutat Res. 2002; 521: 113-9.

56. Wang C, Mayer JA, Mazumdar A, and Brown PH. The rearranged during transfection/papillary thyroid carcinoma tyrosine kinase is an estrogen-dependent gene required for the growth of estrogen receptor positive breast cancer cells. Breast Cancer Res Treat. 2012; 133: 487-500.

57. DerSimonian R and Laird N. Meta-analysis in clinical trials. Control Clin Trials. 1986; 7: 177-88.

58. Mantel $\mathrm{N}$ and Haenszel W. Statistical aspects of the analysis of data from retrospective studies of disease. J Natl Cancer Inst. 1959; 22: 719-48.

59. Begg CB and Mazumdar M. Operating characteristics of a rank correlation test for publication bias. Biometrics. 1994; 50: 1088-101.

60. Egger M, Davey Smith G, Schneider M, and Minder C. Bias in meta-analysis detected by a simple, graphical test. BMJ. 1997; 315: 629-34. 